УДК 94 (571.54)

КАЛЬМИНА Лилия Владимировна - доктор исторических наук, доцент; ведущий научный сотрудник отдела истории, этнологии и социологии Института монголоведения, буддологии и тибетологии СО РАН (670047, Россия, Республика Бурятия, г. Улан-Удэ, ул. Сахьяновой, 6; kalminal@ gmail.com)

ПЛЕХАНОВА Анна Максимовна - доктор исторических наук, доцент; ведущий научный сотрудник отдела истории, этнологии и социологии Института монголоведения, буддологии и тибетологии СО РАН (670047, Россия, Республика Бурятия, г. Улан-Удэ, ул. Сахьяновой, 6; plehanova.aт@ mail.ru)

\title{
ЯРМАРОЧНАЯ ТОРГОВЛЯ В ЗАБАЙКАЛЬЕ В ПОСЛЕДНЕЙ ТРЕТИ ХVIII - ПЕРВОЙ ЧЕТВЕРТИ XX в.: ЭТАПЫ РАЗВИТИЯ
}

\begin{abstract}
Аннотация. При отдаленности Забайкалья от промышленных центров и неразвитости путей сообщения ярмарочная торговля надолго стала здесь основной формой торгового предпринимательства. В своем развитии она прошла три условных этапа. Первый - до проведения Транссибирской магистрали, когда при отсутствии стационарных форм торговли она переживала период расцвета и господствовала безраздельно. Второй - после проведения Великого рельсового пути, когда снизились ярмарочные объемы, произошла децентрализация ярмарочной торговли: на смену крупным ярмаркам пришла масса мелких в селах и деревнях. Однако в целом ярмарочная торговля сохранила свое значение и даже расширила сеть. Задача быстрого восстановления экономики после Гражданской войны потребовала возрождения ярмарочной торговли, в которой первые позиции заняли частные торговцы. Однако, сыграв свою роль в восстановлении товарно-денежных отношений, ярмарочная форма торговли была быстро свернута в соответствии с политикой борьбы с частным капиталом.
\end{abstract}

Ключевые слова: Забайкалье, Бурят-Монгольская АССР, ярмарка, торговые обороты, Транссибирская магистраль, новая экономическая политика

В исследуемый период торговля в экономической структуре региона занимала ведущее место, что было обусловлено слабым развитием промышленности и высокой потребностью в товарах фабричного производства. При отдаленности региона от промышленных центров и неразвитости путей сообщения основными формами торговли долгое время оставались ярмарочная и базарная. Ярмарочная торговля была важным индикатором состояния региональной экономики, поэтому в обзорах Забайкальской области и отчетах военных губернаторов она выделялась в самостоятельный раздел.

Отсчет «ярмарочной» истории Забайкалья следует начать с 1768 г. - времени основания знаменитой Верхнеудинской зимней ярмарки, на которую съезжались торговцы из Иркутска, Нерчинска, Читы, Кяхты, Баргузина, Приамурья. Время ее проведения (последние числа января - начало февраля) определялось сроками установления прочной дороги через Байкал. Верхнеудинская ярмарка не имела четкой специализации, хотя основным предметом торга была мануфактура, составлявшая пятую часть торгового оборота [Иванов, Кальмина, Курас 2012: 108]. По общему обороту товаров, размаху торговых связей она выходила за рамки областного значения и была важным коммерческим центром Забайкалья на всем протяжении XIX в. [Евдокимова 2007: 112-113].

Вокруг Верхнеудинска как одного из узловых межрегиональных ярмарочных центров выстраивались «ярмарочные цепочки» более мелких сезонных и специализированных ярмарок [Шахеров 2011: 135-136]. Наиболее крупными ярмарками Забайкалья были Спасо-Преображенская (в справочной литера- 
туре ее часто называли Чертовкинской - по названию селения, где она проводилась), Агинская и Онинская (Анинская). Главным предметом торга Спасо-Преображенской ярмарки был соленый омуль, время улова которого совпадало со сроками проведения ярмарки - с 1 августа до 20 сентября. На Агинской ярмарке, учрежденной в 1864 г. и проводившейся в первую неделю декабря, «обращались местные сырые произведения», китайские ткани и предметы, необходимые в инородческом быту. Такие же товары привозились на Онинскую ${ }^{1}$ ярмарку в ведомстве Хоринской степной думы, учрежденную в 1801 г. Проводилась она с 25 декабря по 7 января.

В верхнеудинской ярмарочной торговле отчетливо просматриваются несколько тенденций. Во-первых, превышение спроса над предложением. Непроданные товары реализовывались на других торгах в уезде, или их оставляли в местных лавках, чтобы при случае пустить в продажу. Во-вторых, ввиду слабого развития местной промышленности на ярмарке торговали в основном привозными товарами. «Из обзора ярмарки я вынес полное разочарование, писал корреспондент газеты “Восточное обозрение” А. Воткин, - эта ярмарка не была выражением культуры края, так как кой-какие продукты местной производительности утопали в наплыве издалека пришедших товаров» ${ }^{2}$. Закупка товаров на других ярмарках приводила к их существенному удорожанию: продавцам надо было окупить свои затраты по закупке, а также найму и содержанию квартир ${ }^{3}$. В-третьих, заезжие торговцы явно пренебрегали сложившейся конъюнктурой. Привезенные товары часто не соответствовали растущему спросу сибиряков. «Многие приезжают лишь затем, чтобы “поторговать" на ярмарке, воспользовавшись удобным случаем пораспродать кое-что из так называемой “завали”», - не без сарказма отмечал А. Воткин. Неравное положение сибирских торговцев, вынужденных довольствоваться предложенным столичными купцами товаром, было также одной из особенностей сибирской ярмарочной торговли.

1870-1890-е гг. были, тем не менее, временем ее расцвета. Хотя по официальной статистике обороты Верхнеудинской ярмарки редко превышали 2 млн руб., городская управа не без основания подвергала эти цифры сомнению, полагая, что на самом деле они были по крайней мере вдвое больше. Такого же мнения придерживались и наблюдавшие за ярмаркой полицейские чиновники, объяснявшие сознательное занижение торговцами реальных цифр желанием избежать уплаты процентного сбора, в т.ч. за прошлые годы ${ }^{4}$. Оборот Онинской ярмарки за период с 1884 по 1898 г. вырос с 40 тыс. руб. до 90 тыс. 5 Обороты Спасо-Преображенской ярмарки колебались в ту или иную сторону в зависимости от улова омуля.

Транссибирская магистраль дала начало второму этапу истории ярмарочной торговли в регионе. Ожидание этого знаменательного события, обещавшего перевернуть жизнь Забайкалья, соседствовало с опасениями нарушения привычного уклада жизни и упадка традиционных занятий - к примеру, извоза, которым промышляли многие жители Забайкалья 6. И местная печать, и проезжающие через Забайкалье путешественники предрекали Верхнеудинской ярмарке печальную участь «снисхождения до обыкновенного базара» и даже

\footnotetext{
1 Для справочной литературы того времени был характерен такой вариант написания.

2 Восточное обозрение. 1894. № 44.

3 Государственный архив Республики Бурятия (ГАРБ). Ф. 10. Оп. 1. Д. 1939. Л. 70.

4 ГАРБ. Ф. 10. ОП. 1. Д. 520. Л. 42.

5 Обзор Забайкальской области за 1884 г. Чита. 1885. С. 25; Обзор Забайкальской области за 1898 г. Чита. 1899. С. 8.

6 Государственный архив Забайкальского края (ГАЗК). Ф. 1(о). Оп. 1. Д. 2257. Л. 7.
} 
«совершенное прекращение» ${ }^{1}$. Казалось, эти нерадостные для ярмарочной торговли прогнозы полного падения «с первым свистком паровоза» оправдались: в 1901 г. обороты Верхнеудинской ярмарки едва достигли 580 тыс. руб. Доход горожан от сдачи квартир для магазинов приезжим, составлявший ежегодно около 50 тыс. руб., сократился более чем наполовину. Крупные каменные магазины, выстроенные с целью отдачи их внаем на время ярмарки, пустовали ${ }^{2}$. Это было естественным следствием появившейся возможности приобрести товар из первых рук, без закупки его на ярмарках на целый год. Теперь торговец даже с небольшим капиталом мог заключать сделки с оптовыми складами, открывшимися во многих городах вдоль железной дороги, в т.ч. в Верхнеудинске. Однако ярмарочная торговля быстро оправилась от перенесенного стресса и, приспособившись к новым условиям, вновь начала набирать обороты и расширять свою сеть. В 1901 г. открылись Акшинская и Зюльзинская (инородческая) ярмарки в Восточном Забайкалье. В 1903 г. в Верхнеудинске начала торговлю вторая, летняя ярмарка для зимнего снабжения золотых приисков со сроками проведения в августе-сентябре, когда были ясны «виды на урожай» и подведены итоги охотничье-рыболовного сезона ${ }^{3}$. Ярмарка уцелела, раздробившись на множество мелких по селам и деревням, т.к. городская торговля из-за своей отдаленности не могла удовлетворить растущий спрос сельского населения. Ярмарочная торговля продолжалась даже в условиях военного времени. Как указывалось в отчете о Верхнеудинской ярмарке в 1905 г., хотя из-за низкой пропускной способности железной дороги, перевозившей в первую очередь военные грузы, было привезено мало товаров, «покупателей... съехалась масса, и потому торговля была весьма оживленной» 4 .

Причиной «живучести» ярмарочной торговли стала запаздывающая в Забайкалье модернизация торгового предпринимательства. Хотя в Верхнеудинске к этому времени уже открылись несколько крупных стационарных магазинов купцов Второва, Цыгальницкого, Сегельмана, в целом новые формы оптовой и розничной торговли (склады, аукционы) развивались слабо, а биржевые операции не только в Забайкалье, но и вообще в сибирском регионе не имели широкого распространения в силу развитых традиций беспосреднической торговли [Андрющенко 2003: 216]. Экономика Забайкалья не смогла предложить формы торговли, альтернативные ярмарочной, которая и после проведения железнодорожной магистрали продолжала играть главную роль в формировании его торговых связей.

После окончания Гражданской войны в Бурят-Монгольской АССР, образованной Постановлением Президиума ВЦИК РСФСР от 30 мая 1923 г., начинается переход к новой экономической политике. Советская власть, стремясь как можно быстрее выйти из состояния глубокого экономического кризиса, вынуждена была вновь допустить рыночные отношения в экономику после запретительных мер периода «военного коммунизма», используя при этом старые, хорошо известные способы и методы.

Одним из механизмов восстановления товарно-денежных отношений стало возрождение ярмарок, поддерживающих меновые связи между отдельными экономическими районами, что было особенно важно в первые годы нэпа. На территории Бурятии были восстановлены и действовали Верхнеудинская ярмарка,

1 Восточное обозрение. 1894. № 44; Виноградов А. В дальних краях. Путевые заметки и впечатления. M. 1901. C. 185.

2 Сибирский торгово-промышленный календарь на 1904 г. Томск. 1904. С. 193; ГАРБ. Ф. 10. ОП. 1. Д. 2256. Л. 3.

3 ГАРБ. Ф. 10. ОП. 1. Д. 1710. Л. 3.

4 Там же. Д. 1939. Л. 70, 138. 
в Хоринском аймаке - Анинская, в г. Баргузине - Ленско-Баргузинская, в Агинском аймаке - Агинская и др. В условиях бездорожья, удаленности от крупных торговых центров и путей сообщения, низкой плотности населения $\left(1,4\right.$ чел. на 1 кв. км $\left.{ }^{1}\right)$, а также недостаточной товарности хозяйства ярмарочная торговля в республике вновь приобрела большое значение.

Верхнеудинская ярмарка возобновила свою работу 31 января 1924 г. Нарком промышленности и торговли Бурят-Монгольской АССР И.А. Ильин, выступая на открытии ярмарки, указал, что в отличие от дореволюционной - «старой» - ярмарки, где «главными воротилами были “Второвы” и им подобные», в «новой» - советской - «главное участие принимает рабоче-крестьянское государство в лице своих хозяйственных и торговых органов». Председатель ярмарочного комитета Рубенчик в своем приветственном слове отметил, что главная задача ярмарки - «смычка города с деревней, ибо здесь крестьянин найдет место сбыта своего продукта и рабочий обменяет продукт своего труда на продукт сельского хозяйства без вмешательства спекуляции» 2 .

В качестве участников ярмарки зарегистрировались 22 торговых учреждения, из которых большая часть прибыли из Иркутска, в т.ч. Иркутский рабочий производственный кооператив «Игла» и Иркутское отделение всероссийского синдиката «Швейпром». Участникам ярмарки были предоставлены значительные льготы: они отчисляли в пользу ярмарочного комитета лишь $6 \%$ стоимости товаров, из которых 1,5\% поступали в фонд помощи беспризорным детям, $1 \%$ - на развитие воздушного флота, $0,5 \%$ - в пользу инвалидов, $1 \%$ - милиции в виде компенсации за интенсивную охрану района ярмарки. На время ярмарки в городе был организован усиленный санитарно-ветеринарный надзор за состоянием постоялых дворов, за содержанием скота 3 .

В 1925 г. Верхнеудинская ярмарка прошла еще более оживленно. Ярмарочный торг длился 21 день. В ярмарке приняли участие 103 торговые фирмы: 16 государственных организаций, из которых 9 были местными и 7 - приезжими из Иркутска и Канска, 7 кооперативных и 80 частных. Доля участия частного капитала в торговом обороте Верхнеудинской ярмарки составляла $13 \%$ (174 141 руб.), кооперативных организаций - 25\% (332 988 руб.), государственных - 62\% (842 145 руб.). Торговый оборот ярмарки в 1925 г. составил 1349274 руб., где основное место заняли хлеб и фураж - 320271 руб., сырье, главным образом пушнина - 200237 руб., бакалейные и колониальные товары - 169903 руб., москательно-химические - 114179 руб., текстильные - 81276 руб. ${ }^{4}$

Однако уже в 1926 г. ярмарочный торг в столице республике резко сдал свои позиции. По материалам ярмарочного комитета, в качестве участников зарегистрировалась 101 организация, из которых 88 были частными. Однако из крупных были представлены только два павильона кооперативных организаций - Буркоопсоюза и ЦРК «Единение», основное же место занимала мелкая торговля, «так называемая барахолка, украшенная пряниками и конфектами». Сельское население в ярмарке практически не участвовало. Сделки совершались только за наличный расчет (в отличие от дореволюционного периода, когда закупка товаров осуществлялась преимущественно в кредит) [Кальмина 2015: 422]. Преобладающей была розничная торговля, оптовый товар носил случайный характер, поэтому играл незначительную роль. Торговый оборот

\footnotetext{
${ }^{1}$ Российский государственный архив социально-политической истории (РГАСПИ). Ф. 17. ОП. 67. Д. 30. Л. 42.

2 Открытие первой Бурят-Монгольской ярмарки. - Бурят-Монгольская правда. 1924. № 27(125). С. 3.

3 Там же.

4 Бурят-Монгольская АССР: очерки и отчеты. 1925-1926. Верхнеудинск: Госплан БМ АССР. 1927. C. 77 .
} 
составил 193317 руб. «Бурят-Монгольская правда» писала, что, «несмотря на шумиху, поднятую в торговом мире, о том, что Верхнеудинская ярмарка имеет краевое значение как сырьевая ярмарка, результаты ее в этом году очень плачевны. С трудом и натяжкой ее можно будет назвать ярмаркой лишь местного значения» 1 . Причинами неудач ярмарочного торга в 1926 г., по мнению современников, стали не только запоздалая подготовка к ярмарке и неурожай пшеницы, но и организованные в сельской местности государственными и кооперативными организациями кампании по заготовке сельскохозяйственного сырья, которые снимали большую часть крестьянского предложения. Кроме того, на судьбу Верхнеудинской ярмарки оказал влияние ежегодно увеличивающийся охват сельских районов более модернизированными - стационарными формами государственно-кооперативной торговли.

Несмотря на сохраняющийся товарный голод (в 1927-1928 гг. потребности населения в хлопчатобумажных тканях были удовлетворены на 50\%, в металлоизделиях - на $62 \%$, в чае - на $40 \% 2$ ), дальнейшая необходимость в ярмарках отпала, прежде всего по идеологическим причинам. Наличие ярмарочного торга, предоставлявшего широкое поле деятельности для частного предпринимательства, противоречило развернувшейся со второй половины 1920-х гг. политике, направленной на борьбу с частным капиталом. Окончательное свертывание ярмарочной торговли в последующие годы по всей стране было следствием отказа от нэпа, отражением в целом советской экономической политики, отвергнувшей рыночные отношения и разнообразие форм собственности в пользу централизованной планово-распределительной системы.

«Ярмарочный ренессанс» в советском государстве оказался непродолжительным по времени, однако ярмарочная сеть, возрожденная в период нэпа, сыграла значительную роль в восстановлении разрушенных в условиях военного времени товарно-денежных отношений.

Таким образом, ярмарочная торговля в Забайкалье в своем развитии прошла три этапа. Первый этап - время монополии ярмарочной формы торгового предпринимательства - начался с основания ярмарочных торгов и продолжился до конца XIX в. Начало второму этапу положило проведение Транссибирской магистрали, снизившей объемы и изменившей формы ярмарочной торговли. Третий этап - возрождение ярмарок в условиях новой экономической политики с целью восстановления товарно-денежных отношений.

Статья подготовлена в рамках государственного задания (проект ХII.191.1.1 «Трансграничье России, Монголии и Китая: история, культура, современное общество», № $A A A A-A 17-117021310269-9)$.

\section{Список литературы}

Андрющенко Б.К. 2003. Сфера обмена Сибири как показатель уровня модернизации. - Сибирское общество в контексте модернизации XVIII-XX вв.: сборник материалов всероссийской конференции. Новосибирск, 22-23 сент. 2003 г. (под ред. В.А. Ламина). Новосибирск: ИИ СО РАН. С. 212-218.

Евдокимова С.В. 2007. Социально-экономическое развитие городов Забайкалья в $X V I I-X I X$ вв. Улан-Удэ: Изд-во Бурятского госуниверситета. 248 с.

Иванов А.А., Кальмина Л.В., Курас Л.В. 2012. Забайкальская периферия на переломе эпох (1880-1920-е г2.). Иркутск: Оттиск. 300 с.

\footnotetext{
1 Ярмарка не удалась. - Бурят-Монгольская правда. 1926. № 62(755). С. 8.

2 РГАСПИ. Ф. 17. ОП. 21. Д. 562. Л. 337.
} 
Кальмина Л.В. 2015. Верхнеудинская ярмарка как социокультурный феномен. - Иркутский историко-экономический ежегодник. Иркутск: Изд-во БГУЭП. С. 420-426.

Шахеров В.П. 2011. Экономика сибирского дореформенного города (на материалах городов Байкальской Сибири). Иркутск: Изд-во Иркутского госуниверситета. $256 \mathrm{c}$.

KAL'MINA Liliya Vladimirovna, Dr.Sci. (Hist.), Associate Professor; Leading Scientific Researcher of the Department of History, Ethnology and Sociology, Institute for Mongolian, Buddhist and Tibetan Studies, Siberian branch of the Russian Academy of Sciences (6 Sah'janovoj St, Ulan-Ude, Republic of Buryatia, Russia, 670047; kalminal@gmail.com)

PLEKHANOVA Anna Maksimovna, Dr.Sci. (Hist.), Associate Professor; Leading Scientific Researcher of the Department of History, Ethnology and Sociology, Institute for Mongolian, Buddhist and Tibetan Studies, Siberian branch of the Russian Academy of Sciences (6 Sah'janovoj St, Ulan-Ude, Republic of Buryatia, Russia, 670047; plehanova.am@mail.ru)

\title{
FAIR TRADE IN TRANSBAIKALIA IN THE LAST THIRD OF THE $18^{\mathrm{TH}}$ - THE FIRST QUARTER OF THE $20^{\text {TH }}$ CENTURY: STAGES OF DEVELOPMENT
}

\begin{abstract}
As a result of distance barriers of Transbaikalia from industrial centers and the underdevelopment of communications, fair trade for a long time became the main form of commercial entrepreneurship. In its development, it went through three stages. The first was before the Trans-Siberian Railway construction, when, in the absence of stationary forms of trade, it experienced a period of flourishing and dominated completely. The second was after its construction, when fair volumes declined, fair trade was decentralized: a large number of small fairs in villages replaced the large fairs. However, in general, fair trade retained its value and even expanded the network. The task of rapid economic recovery after the Civil War demanded the revival of fair trade, in which private traders took the first positions. However, having played a role in the restoration of goods/money relationship, the fair form of trade was quickly curtailed in accordance with the policy of the struggle with private capital.
\end{abstract}

Keywords: Transbaikalia, Buryat-Mongol ASSR, fair, trading circulation, Trans-Siberian Railway, new economic policy 